Making All the Difference 



\section{MARTHA MINOW}

\section{Making All the Difference}

INCLUSION, EXCLUSION, AND AMERICAN LAW

\section{Cornell University Press}

Ithaca and London 
Copyright (1) I 990 by Cornell University

All rights reserved. Except for brief quotations in a review, this book, or parts thereof, must not be reproduced in any form without permission in writing from the publisher. For information, address Cornell University Press, Sage House, 5 I 2 East State Street, Ithaca, New York 14850.

First published 1990 by Cornell University Press.

Third printing 1994 .

International Standard Book Number 0-8014-2446-1

Library of Congress Catalog Card Number 90-1754

Printed in the United States of America

Librarians: Library of Congress cataloging information

appears on the last page of the book.

The paper in this book meets the minimum requirements of the American National Standard for Information Sciences-Permanence of Paper for Printed Library Materials, ANSI Z 39.48-1984. 
To Burton Minow 
